\title{
Ireland Among the Nations of the Earth: Ireland's Foreign Relations from 1923 to 1949
}

Francis M. Carroll

\section{(2) OpenEdition \\ 1 Journals}

\section{Electronic version}

URL: http://journals.openedition.org/etudesirlandaises/4796

DOI: 10.4000/etudesirlandaises.4796

ISSN: 2259-8863

\section{Publisher}

Presses universitaires de Rennes

\section{Printed version}

Date of publication: 15 June 2016

Number of pages: $35-52$

ISBN: 978-2-7535-5091-9

ISSN: 0183-973X

\section{Electronic reference}

Francis M. Carroll, «Ireland Among the Nations of the Earth: Ireland's Foreign Relations from 1923 to 1949 », Études irlandaises [Online], 41-1 | 2016, Online since 15 June 2018, connection on 02 May 2019. URL : http://journals.openedition.org/etudesirlandaises/4796; DOI : 10.4000/ etudesirlandaises.4796 


\title{
Ireland among the Nations of the Earth: Ireland's Foreign Relations from 1923 to 1949
}

\author{
Francis M. Carroll \\ St. John's College - University of Manitoba
}

Abstract

Irish foreign relations shaped the process of Ireland's emergence as a sovereign nation state. The channels through which this independent status were achieved and recognized were membership in the League of Nations, in which Ireland took an increasingly prominent part by the 1930s; Commonwealth affairs, wherein Ireland worked persistently to expand the independent role of the Dominions; and bi-lateral relations, whereby Ireland expeditiously established diplomatic relations with the United States, France, Germany and the Vatican. By the late 1930s Ireland was sufficiently autonomous to pursue a policy of neutrality during the Second World War, despite the involvement of Britain and the rest of the Commonwealth, and by 1949, now as the Republic of Ireland, to unilaterally exit the Commonwealth. Ireland's foreign policy consolidated its independence.

Keywords: Irish sovereignty, League of Nations, Commonwealth affairs, bi-lateral relations, republicanism

\section{Résumé}

Les relations internationales ont été au cour du processus d'émergence de l'Irlande comme étatnation souverain. Les voies par lesquelles cette indépendance fut acquise et reconnue furent l'appartenance à la Société des Nations où l'Irlande a joué un rôle de premier plan dans les années 1930; les Affaires du Commonwealth, au sein desquelles l'Irlande oeuvra en permanence pour étendre le degré d'indépendance des Dominions; et les relations bilatérales qui ont permis à l'Irlande d'établir très rapidement des relations diplomatiques avec les Etats-Unis, la France, l'Allemagne et le Vatican. Avant la fin des années 1930, l'Irlande était suffisamment autonome pour adopter une politique de neutralité pendant la Seconde Guerre mondiale en dépit de la participation active de la GrandeBretagne et du reste du Commonwealth, et pour sortir unilatéralement du Commonwealth en 1949 en tant que république d'Irlande. La politique étrangère irlandaise consolida son indépendance.

Mots clés : Souveraineté irlandaise, Société des Nations, Affaires du Commonwealth, relations bilatérales, républicanisme

"When my country takes her place among the nations of the earth, then, and not until then, let my epitaph be written." These were the stirring words that concluded Robert Emmet's famous speech from the dock in 1803, and they 
became a rallying cry for Irish nationalists for over a century. Historians, however, have had a complicated relationship with these sentiments. They have certainly quoted Emmet regularly, and the Irish history they have written, consciously or unconsciously, has been largely a nationalist narrative. Irish history has for the most part focused on the struggle for political, religious, and economic rights, and the emergence of an Irish nation - a nation in the sense of some kind of sovereign entity $^{1}$. All of this has been important, showing the step-by-step process through which Ireland struggled to obtain self-government and independence and to assert its cultural identity. However, Emmet's words ask that he be judged "when his country takes her place among the nations of the earth", and that is literally a somewhat different narrative - Ireland within the international community. A sampling of the leading histories of Ireland illustrates the point. The general histories by F.S.L. Lyons, Roy Foster, Alvin Jackson, and Thomas Bartlett, and the twentieth-century histories by J.J. Lee and Diarmaid Ferriter devote anywhere from a few lines to only several pages to foreign affairs matters in their substantial books - the League of nations, Dominion affairs, diplomatic recognition, and bilateral relations. The exceptions to this generalization are the discussions of the land annuities-trade dispute with Britain in the 1930s, the issues surrounding the treaty ports, and Irish neutrality in the Second World War'. It is the thesis of this article that foreign affairs, although seriously studied only in the last thirty years and almost exclusively by diplomatic historians, have also been a major part of the emergence of the Irish state and should be integrated into the national narrative ${ }^{3}$.

It is surprising to be reminded that Dermot Keogh's classic work, Ireland \& Europe, 1919-1948, was published as recently as 1988, and Michael Kennedy's Ireland and the League of Nations, 1919-1946 came out only in 1996. Happily, other historical monographs have followed ${ }^{4}$. Part of the credit for this has been

1. The title of Lawrence McCaffrey's widely read textbook, Ireland: From Colony to Nation State, illustrates the point. Lawrence J. McCaffrey, Ireland: From Colony to Nation State, Englewood Cliffs, Prentice-Hall, Inc., 1979. Max Beloff uses the terminology somewhat differently. "It [Ireland] was not in its own view a colony that had achieved self-rule but a subject nation that had at last been recognized, though only in a truncated form." Max Beloff, Dream of Commonwealth, 1921-42, Basingstoke, Macmillan Press, Ltd., 1989, p. 77-78.

2. Three major general histories of Ireland are, F.S.L. Lyons, Ireland Since the Famine, London, Weidenfeld and Nicholson, 1971; Roy Foster, Modern Ireland, 1600-1972, London, Allen Lane, 1988; Alvin Jackson, Ireland, 1789-1998, Oxford, Blackwell Publishers Ltd., 1999; and Thomas Bartlett, Ireland, A History, Cambridge, Cambridge University Press, 2010. The standard works on twentieth century Ireland are, Joseph J. Lee, Ireland, 1912-1985: Politics and Society, Cambridge, Cambridge University Press, 1989; and Diarmaid Ferriter, The Transformation of Ireland, Woodstock, The Overlook Press, 2007. Shorter works include, John A. Murphy, Ireland in the Twentieth Century, Dublin, Gill and Macmillan, Ltd., 1975; Ronan Fanning, Independent Ireland, Dublin, Helicon Limited, 1983; and David Harkness, Ireland in the Twentieth Century: Divided Ireland, Basingstoke, Macmillan Press, Ltd., 1996.

3. Michael Kennedy warns that it is a mistake to see Ireland exclusively "in insular national terms divorced from concurrent events in Europe and a wider world..." Michael Kennedy, Ireland and the League of Nations 19191946: International Relations, Diplomacy and Politics, Dublin, Irish Academic Press, 1996, p. 251.

4. Dermot Keogh, Ireland and Europe, 1919-1948, Dublin, Gill and Macmillan, 1988; and Michael Kennedy, 
the consolidation in the late 1980s and early 1990s of the old Public Record Office at the Four Courts and the State Paper Office at Dublin Castle into a new National Archives of Ireland on Bishop's Street. This was major structural change in the management of Irish government records, and, together with the release of manuscript material from the Department of Foreign Affairs and the Department of the Taoiseach, it has opened the door to serious research on foreign relations ${ }^{5}$. Equally important has been the publication of a monumental series of Documents on Irish Foreign Policy, undertaken jointly by the Department of Foreign Affairs and the Royal Irish Academy. Volume one, 1919 to 1922, came out in 1998 and the series is now up to volume nine, 1948-1951. The original editors were Ronan Fanning, of University College Dublin; Michael Kennedy, from the Royal Irish Academy; Dermot Keogh, from University College Cork; and Eunan O'Halpin, from Trinity College; and they were guided by an Advisory Board that included representatives from the Department of Foreign Affairs and the National Archives. The publication of this series of Documents on Irish Foreign Policy places Ireland in line with many other nation states, led by the United States, in making available to the public printed copies of the most important documents shaping their countries' foreign relations. Of course, historians demand more than official publications and government documents to write history according to contemporary standards, but together with the manuscript materials available in the National Library of Ireland and particularly the University College Dublin archives, containing the papers of several members of W.T. Cosgrave's government and more recently the de Valera papers, the opportunity now exists for sophisticated research and writing about Ireland's early diplomatic relations with the international community ${ }^{6}$.

Of course, it should be acknowledged that Ireland had something of an international presence while still an integral part of the British Empire. The history of the sixteenth, seventeenth and eighteenth centuries is closely tied to the numerous Irish links to the European continent. The Catholic Church was a consistent link and every major power in Europe had in its service at least one Irish regi-

op. cit. Two more recent collections of essays are, Michael Kennedy and Joseph Morrison Skelly (eds.), Irish Foreign Policy, 1919-1966: From Independence to Internationalism, Dublin, Four Courts Press, 2000; and Ben Tonra, Michael Kennedy, John Doyle and Noel Dorr (eds.), Irish Foreign Policy, Dublin, Gill \& Macmillan, 2012.

5. Gerard O’Brien, Irish Governments and the Guardianship of Historical Records, 1922-72, Dublin, Four Courts Press, 2004. The Royal Irish Academy also began publication of the journal, Irish Studies in International Affairs, in 1979 , focused on both international relations and history.

6. Extensive new biographies of both Cosgrave and de Valera are needed, but several of the existing studies devote some attention to questions of international relations during their time as the head of government. See Michael Laffan, Judging W.T. Cosgrave: The Foundation of the Irish State, Dublin, Royal Irish Academy, 2014; The Earl of Longford and Thomas P. O’Neill, Eamon De Valera: A Biography, Boston, Houghton Mifflin Company, 1971; and Tim Pat Coogan, De Valera: Long Fellow, Long Shadow, London, Arrow Books, 1995. 
ment made up of exiles and adventurers defying English claims to allegiance. The bicentennial of the Rising of 1798 generated extraordinary studies of the French connection during the Revolution, and of course the Fenians in the 1860s have been the subject of steady interest in the US and Canada as well as in Ireland. Jérôme aan de Wiel's new book, The Irish Factor, 1899-1919: Ireland's Strategic and Diplomatic Importance for Foreign Powers, has shed new light on how much Ireland was taken into account in international relations during the early years of the twentieth century ${ }^{7}$. Studies of the Home Rule Crisis of 1912-1914, the 1916 Rising, the Irish efforts at the Paris Peace Conference of 1919, the AngloIrish War, and particularly Eamon de Valera's trip to the United States in 1919 and 1920, have all contained an international component. Various Irish nationalist groups, the Irish Republican Brotherhood, for example, attempted to open contacts with foreign countries (Germany, primarily), and the First and Second Dáil Éireann governments set up a putative Ministry of Foreign Affairs (second in expenditures to military affairs $)^{8}$. The centennials of the First World War and the 1916 Rising will unquestionably stimulate historians to consider these international questions with fresh documents and new insights.

It was the Anglo-Irish Treaty of 1921 that gave Ireland a crucial element of credibility for international purposes. The Anglo-Irish Treaty established the twentysix counties of southern Ireland as a "Dominion", which was to be called the Irish Free State and remain a member of the British Empire, soon to be referred to as the British Commonwealth of Nations. The King remained the head of state and an oath of allegiance to the sovereign was required. These concessions seriously divided those Irish who had fought for an Irish Republic. These divisions led to the outbreak of the Civil War in June of 1922, which was not put down until May of 1923, during which time the government of the new Irish Free State came into being. The divisions within Irish society colored Irish public life for several

7. Jérôme aan de Wiel, The Irish Factor, 1899-1919: Ireland's Strategic and Diplomatic Importance for Foreign Powers, Dublin, Irish Academic Press, 2008. For a good brief account of historic Irish links abroad, see Patrick Keatinge, A Place Among the Nations: Issues of Irish Foreign Policy, Dublin, Institute of Public Administration, 1978, p. 9-63. Also useful is Stephen Hartley, The Irish Question as a Problem in British Foreign Policy, 1914-18, New York, St. Martin's Press, 1987.

8. See Charles Callan Tansill, America and the Fight for Irish Freedom, 1866-1922, New York, Devin-Adair Company, 1957; Alan J. Ward, Ireland and Anglo-American Relations, 1899-1921, London, Weidenfeld and Nicholson, 1969; and Francis M. Carroll, American Opinion and the Irish Question, 1910-23, Dublin, Gill and Macmillan, 1978 and New York, St. Martin's Press, 1978. For Irish and Irish-American activity at the Paris Peace Conference, see Francis M. Carroll (ed.), The American Commission on Irish Independence, 1919: The Diary, Correspondence and Report, Dublin, Irish Manuscript Commission, 1985; and Pierre Ranger, "The World in Paris and Ireland too: The French Diplomacy of Sinn Féin, 1919-1921”, Études irlandaises, vol. 36, n 2 (2011), p. 39-57. For de Valera's mission to the United States, see Patrick McCartan, With De Valera in America, Dublin, Fitzpatrick, Ltd., 1932; Katherine O’Doherty, Assignment America: De Valera's Mission to the United States, New York, De Tanko Publishers, 1957; and Dave Hannigan, De Valera in America: The Rebel President's 1919 Campaign, Dublin, O’Brien Press, 2008. 
generations and determined the context within which the Irish foreign affairs were to be shaped during the next twenty-five years?

Ignoring the shortcomings of the Anglo-Irish Treaty, what did "Dominion status" mean for the Irish Free State? Was Ireland still a colony or was it independent? This was a fair question. In 1921, 1922, and 1923 it was not entirely clear $^{10}$. Canada was the first dominion, being given "Dominion status" in 1867. This had provided Canada with complete political independence, but then Canada had been comfortable with membership in the British Empire and the Commonwealth and to some extent looked to Britain for protection. However, during the First World War the now several dominions made substantial contributions to the war effort, as a result of which they, and even Canada, expected some input into the decision making process. This was facilitated through the creation of an Imperial War Cabinet - meetings of the British and dominion Prime Ministers on a near equal basis. Thus, although the Dominions had been brought into the war by the decision of the British government, it was highly significant that they individually signed the Versailles Treaty ending the war. The dominions also entered the new League of Nations separately with other sovereign nations, rather than merely as part of a British delegation. So by 1922 and 1923, despite the acknowledgement of the King as the head of state and affiliation with Great Britain, the dominions enjoyed the status and practice of nation states international legal persons ${ }^{11}$.

When the Irish Free State came into being in December 1922 it already had the makings of both a diplomatic service and a foreign policy. The Dáil governments had sent substantial missions to Washington and Paris and envoys to Germany, Spain, Italy, and the Vatican. Joseph P. Walshe, Timothy Smiddy, Michael MacWhite, Sean Lester, John Chartres, and Charles Bewley succeeded to positions in the Free State diplomatic service, having started out representing the Dáil government ${ }^{12}$. Count Plunkett was the first Dáil Minister of Foreign

9. See F.S.L. Lyons, Ireland Since the Famine, J.J. Lee, Ireland, 1912-1985, and Diarmaid Ferriter, The Transformation of Ireland.

10. For discussions of what "Dominion status" meant in the 1920s see, A. Lawrence Lowell, "The Treaty-Making Power of Canada", Foreign Affairs, vol. 2, no 1 (1923/24), p. 12-22; Herbert A. Smith, "Diplomacy and International Status", Canadian Bar Review, vol. 2, no 4 (April, 1924), p. 231-41; and Ciphos. D. Allin, "Recent Developments in the Constitutional and International Status of British Dominions", Minnesota Law Review, vol. $10, \mathrm{n}^{\circ} 100$ (1925-26), p. 100-22.

11. Some of these same issues are raised by Nicholas Mansergh in "Ireland and the British Commonwealth of Nations: The Dominion Settlement", in Desmond Williams (ed.), The Irish Struggle, 1916-1926, London, Routledge \& Kegan Paul, 1966, p. 129-39; and Roy E. Holland, Britain and the Commonwealth Alliance, 1918-39 (London, Macmillan Press, 1981), p. 1-23.

12. Patrick Keatinge, "The Formative Years of the Irish Diplomatic Service", Eire-Ireland, vol. 6, no 1 (Fall, 1971), p. 57-71; Dermet Keogh, op. cit., p. 5-33. Short sketches of the early Irish diplomats now exist in the Dictionary of Irish Biography, but more extensive works are Aengus Nolan, Joseph Walshe: Irish Foreign Policy, 19221946, Cork, Mercier Press, 2008; Dermot Keogh, "Profile of Joseph Walshe, Secretary, Department of Foreign 
Affairs, followed eventually by George Gavan Duffy, who in turn was succeeded in July 1922 by Desmond FitzGerald, who then became the first Free State Minister for External Affairs in December 1922. The thrust of the Dáil foreign policy had been primarily to obtain diplomatic recognition from the international community as a weapon to force Britain to concede Irish independence. In the aftermath of the Anglo-Irish Treaty and the Civil War, the Free State government had somewhat more complex needs. It still had to establish itself among the international community of nations, and it also had to demonstrate to both its domestic constituency and the overseas emigrant community that the Irish Free State was a sovereign state. To that end it was obliged to focus on "identity, legitimacy, symbolism, [and] status", in the words of Conor Cruise O'Brien, an early commentator on foreign affairs. The Free State, under the government of William T. Cosgrave, as Michael Kennedy has pointed out, pursued three tracks to establish its international presence: League of Nations policy, Commonwealth policy, and bi-lateral relations ${ }^{13}$.

Membership in the League of Nations was the first track to yield results. Although warmly discussed by the Provisional government during the second half of 1922, a formal application was not submitted to the League secretariat until 17 April 1923. The Irish Free State was admitted to the Assembly of the League at the next meeting in Geneva on 10 September 1923. President of the Executive Council William T. Cosgrave personally led the Irish delegation and addressed the Assembly. Within ten days the Irish delegation began work to have the Anglo-Irish Treaty registered as an "international engagement", with the intention of securing world recognition of the document as the basis for the Irish state. Furthermore, just below the surface was the thought that the Irish government could turn to the Permanent Court of International Justice for a resolution of the Northern Ireland boundary question if the Boundary Commission authorized in the Treaty did not work out. The British government wrote to the League Secretary General that the document was a domestic agreement, but the Treaty was registered nonetheless ${ }^{14}$. This action

Affairs, 1922-1946”, Irish Studies in International Affairs, vol. 3, nº 2 (1990), p. 59-80; Douglas Gageby, The Last Secretary General: Sean Lester and the League of Nations, Dublin, Town House, 2000; Paul McNamara, Sean Lester, Poland and the Nazi Takeover of Danzig, Dublin, Irish Academic Press, 2008; Brian P. Murphy, John Chartres: Mystery Man of the Treaty, Dublin, Irish Academic Press, 1991; Charles Bewley, Memoirs of a Wild Goose, Dublin, Lilliput Press, 1989; and Andreas Roth, Mr. Bewley in Berlin: Aspects of the Career of an Irish Diplomat, 1933-1939, Dublin, Four Courts Press, 2000.

13. Conor Cruise O'Brien, "Ireland in International Affairs", in Owen Dudley Edwards (ed.), Conor Cruise O'Brien Introduces Ireland (London, Andre Deutsch, 1969), p. 104; Michael Kennedy, Ireland and the League of Nations, op. cit., p. 13; and Gerard Keown, "Taking the World Stage: Creating an Irish Foreign Policy in the 1920s", in Ben Tonra, Michael Kennedy, John Doyle and Noel Dorr (eds), op. cit., p. 25-43.

14. Michael Kennedy, Ireland and the League of Nations, op. cit., p. 27-72. Cosgrave is sometimes held to a statement made in June of 1922 while Minister of Local Government in the Provisional Government, that he regarded foreign affairs as important only as it related to commercial activity, although when he assumed the Presidency of the Executive Council of the Free State he took quite a large role in Ireland's external affairs. 
was the first of several steps taken at the League to distinguish the Irish Free State from Great Britain and to give the Irish delegation a high profile in Geneva. As well as serving on various committees, Ireland took an increasingly prominent role among the smaller nations in the League. Ireland distinguished itself in 1926 by standing for election by the Assembly to the League Council in opposition to the slate of candidates based on geographical representation; in 1927 Ireland strongly supported the election of Canada to the Council; and in 1930 Ireland successfully won election to a seat on the Council itself for the important three years of 1930 to $1933^{15}$. These gestures were effective assertions of independence as both a small nation and a Dominion, prompting Patrick McGilligan, the Minister of External Affairs, to say, "we are recognized at Geneva as one of the main upholders of the complete independence of the smaller States ${ }^{16}$..." Historians such as John P. McCarthy have downplayed the importance of Irish participation in League affairs, which with the benefit of hindsight may be true, but at the time the League was the great hope for the future ${ }^{17}$. These activities were matters of great importance for Ireland's standing in the international community.

The formation of a Fianna Fáil government in 1932 projected Eamon de Valera into prominence as both President of the Executive Council and Minister of External Affairs. De Valera pursued policies at the League similar to those of Cosgrave, but de Valera was presented with a far better platform when Ireland was given the rotating Presidency of the League Council and made Acting President of the Assembly. Although de Valera had been critical of the League in 1919, in his opening speech to the Assembly on 26 September 1932 he supported the League and wanted it to work to protect small nations through collective security, but he recognized that to be effective the League Covenant had to be enforced and member states had to fulfill their obligations. De Valera warned that world opinion was losing faith in the capacity of the League to protect peace and stability. "People are complaining that the League is devoting its activity to matters of secondary or very minor importance, while the vital international problems of the day... are being shelved or postponed or ignored", de Valera told the Assembly ${ }^{18}$. His frank language went beyond the usual diplomatic platitudes and earned him stature as a statesman at home and enhanced Ireland's reputation

George Gavan Duffy to W.T. Cosgrave, 20 June 1922, Documents on Irish Foreign Policy, Volume I, 1919 to 1922, Dublin, Royal Irish Academy, 1998, p. 467.

15. Michael Kennedy, Ireland and the League of Nations, op. cit., p. 129-88.

16. Dáil Eireann deb., vol. 39, col. 1281; 1 July 1931.

17. For his less enthusiastic view of the League of Nations, see John P. McCarthy, Kevin O'Higgins: Builder of the Irish State, Dublin, Irish Academic Press, 2006, p. 233-34.

18. Norman MacQueen, "Éamon de Valera, the Irish Free State, and the League of Nations, 1919-46", EireIreland, vol. 17, $\mathrm{n}^{\circ} 4$ (Winter, 1982), p. 110-27. For the text of his speech to the League of Nations Assembly on 26 September 1932, see "League of Nations - The Testing Time", in Maurice Moynihan (ed.), Speeches and Statements by Eamon De Valera, 1917-1973, Dublin, Gill and Macmillan, 1980, p. 219-23. 
as an international force to be taken seriously. This was particularly important because de Valera still carried something of the stigma of an irresponsible rebel ${ }^{19}$. During the Manchurian crisis in 1932 and the Abyssinian crisis of 1934-1936, de Valera warned that the League must take action to enforce international law and preserve peace ${ }^{20}$. The League, of course, became increasingly side-tracked as a collective security organization as the international situation in Europe and the Far East deteriorated in the late 1930s. Ironically, de Valera was elected to the Presidency of the League Assembly in 1938, just as Adolph Hitler was threatening Czechoslovakia, although by that time he had concluded that Ireland must look to its own resources and to a policy of strict neutrality in the coming conflict in Europe. De Valera had to admit to the Dáil as early as 1936 that the League "does not command our confidence 21 ".

The second avenue for Irish Free State objectives in the 1920s was its Commonwealth policy. Of course for anti-Treaty nationalists, membership in the Commonwealth itself was proof positive that the Irish Free State was still a colony. Nevertheless, Cosgrave led a delegation to the Imperial Conference in London on 1 October 1923 and was warmly welcomed. He found a situation in which the delegations from South Africa and Canada were also determined to assert sovereignty and independence within the Commonwealth. During the 1926 Imperial Conference the Irish delegation worked closely with the South Africans and Canadians to produce a statement of what was by then the working relationship between Britain and the Dominions. These efforts emerged in the so-called Balfour Declaration, stating that Great Britain and the Dominions were "equal in status, in no way subordinate one to another in any of their domestic or

19. Kennedy notes that de Valera "developed a high profile at the League and was soon renowned as a statesman of world repute”. Michael Kennedy, Ireland and the League of Nations, op. cit., p. 162 and 189-225.

20. De Valera was chairman of the Council session that accepted the Lytton Report on Manchuria and despite considerable support for Italy in Ireland voted for sanctions against Italy over that country's invasion of Abyssinia. In a speech to the League, de Valera said, "Make no mistake, if on any pretext whatever we were to permit the sovereignty of even the weakest state among us to be unjustly taken away, the whole foundation of the League would crumble into dust." Dermot Keogh, Ireland and Europe, op. cit., p. 57-61. For the text of de Valera’s speech to the Dáil on 18 June 1936 on the League's failure to deal with the Abyssinian crisis, and for his the text of his speech to the League Assembly on 2 July 1936 on the same topic, see "Failure of the League of Nations", and "Bitter Humiliation", in Maurice Moynihan (ed.), Speeches and Statements by Eamon De Valera, op. cit., p. 273-77 and 282-85.

21. Patrick Keatinge, The Formulation of Irish Foreign Policy, Dublin, Institute for Public Administration, 1973, p. 24. Also see, Michael Kennedy, "The Irish Free State and the League of Nations, 1922-32: The Wider Implications", Irish Studies in International Affairs, vol. 3, no 4 (1992), 9-23; Stephen Barcroft, "Irish Foreign Policy at the League of Nations, 1929-1936", Irish Studies in International Affairs, vol. 1, n 1 (1979), 19-29; and Norman MacQueen, "Eamon de Valera, the Irish Free State, and the League of Nations, 1919-46", op. cit., p. 110-27. For the text of de Valera's radio message to the United States through the League broadcasting studio in Geneva on 25 September 1938 on the Sudeten crisis, see "Peace or War?" in Maurice Moynihan (ed.), Speeches and Statement of Eamon De Valera, op. cit., p. 355-58. 
external affairs ${ }^{22} \ldots$ " The conclusion was that these communities were united only by a common loyalty to the Crown. This was a remarkably clear statement of the functioning sovereignty and independence of the Dominions, giving rise to the famous quip by Kevin O'Higgins in response to the claim by the South African premier that the Dominions had brought home the bacon, yes, "Irish bacon ${ }^{23 "}$. The possibility of legislative supremacy was also removed by the Statute of Westminster in 1931, which revoked nineteenth century legislation that gave Parliament the power to invalidate laws passed by colonial assemblies (similar to the Declaratory Acts of the $18^{\text {th }}$ century) and acknowledged the claims in the Balfour Declaration that the Dominion legislatures were independent from any legislation passed by the British Parliament. Patrick McGilligan could tell the Dáil that "the system which it took centuries to build up had been brought to an end by four years of assiduous collaboration between the lawyers and the statement of the States of the Commonwealth ${ }^{24}$ ". The Cosgrave government committed itself to making the Commonwealth work for Ireland's advantage, and in a lawyerly manner the door was opened for a re-thinking of the relationship between the Irish Free State and Great Britain ${ }^{25}$. Once again de Valera was the beneficiary of the Cosgrave government's accomplishments. When he came to power in 1932, de Valera could claim on the basis of the Balfour Declaration and the Statute of Westminster that the Irish legislature had the power to amend and change the terms of the Anglo-Irish Treaty and the constitution of the Irish Free State ${ }^{26}$.

22. Memorandum of Joseph P. Walshe on External Affairs and the Imperial Conference, 1 June 1927, Documents on Irish Foreign Policy, Volume III, 1926-1932, Dublin, Royal Irish Academy, 2002, p. 129-31; and David Harkness, The Restless Dominion: The Irish Free State and the British Commonwealth of Nations, 1921-31 (New York, New York University Press, 1969), p. 87-134.

23. Terence de Vere White, Kevin O'Higgins, Tralee, Anvil Books, 1966, p. 223. For the constructive role of Kevin O’Higgins at the 1926 Imperial conference, see McCarthy, Kevin O'Higgins, p. 234-37. John P. Deidre McMahon dismisses much of the Commonwealth discussion of Dominion status with the phrase "a lot of cloudy waffle about indivisible crowns and indissoluble unity", but Donal Lowry makes a strong argument for the lasting importance of the Commonwealth connection for Ireland. See Deidre McMahon, "Ireland, the Empire, and the Commonwealth", in Kevin Kenny (ed.), Ireland and the British Empire, New York, Oxford University Press, 2004, p. 221; and Donal Lowry, "The Captive Dominion: Imperial Realities Behind Irish Diplomacy, 1922-49”, Irish Historical Studies, vol. 36, nº 142 (November, 2008), p. 202-26.

24. Dáil Éireann deb., vol. 39, col. 2291, 16 July 1931.

25. Roy E. Holland commented that the early Irish Free State representatives were not "revolutionaries" so much as "good liberals implementing a program of efficient government". Roy E. Holland, Britain and the Commonwealth Alliance, op. cit., p. 53-67 and 153. Deirdre McMahon observed about the Cosgrave government's "achievements on the international stage, particularly in the shaping of the Commonwealth, were distinguished but fatally lacked public appeal”. Deirdre McMahon, Republicans and Imperialists: Anglo-Irish Relations in the 1930s, New Haven, Yale University Press, 1984, p. 2. Also see David Harkness, The Restless Dominion, op. cit., p. 173-248; and Nicholas Mansergh, "Ireland and the British Commonwealth of Nations: The Dominion Settlement”, op. cit., p. 129-39. For the Irish view of the Statute of Westminster, see Press Statement by Patrick McGilligan on the Statute of Westminster, 11 December 1931, Documents on Irish Foreign Policy, Volume III, 1926-1832, p. 883-84.

26. Ronan Fanning, Independent Ireland, op. cit., p. 111-20; and Roy F. Holland, Britain and the Commonwealth Alliance, op. cit., p. 152-66. 
Bi-lateral relations were still the third way the Irish Free State could pursue its independence. As mentioned before, the First and Second Dáil governments had worked very actively to devise a foreign policy that sought international recognition and had created the beginnings of a diplomatic service that was serving in several missions abroad when the Irish Free State came into existence. However, in 1922 and 1923 no Dominion had actual diplomatic relations with a foreign power. Was this possible? During the First World War the Canadian government felt the need for direct relations with the United States and subsequently worked out the protocols with both the British and the American governments, although no immediate appointment was made ${ }^{27}$. Acting on this Canadian initiative, the Free State government arranged for Timothy A. Smiddy to be received as Irish Minister to the United States on 7 October 1924. This was the first Dominion diplomat accredited in a foreign capital, and its realization was in the view of the acting secretary of the Department of External Affairs, "the main accomplishment of our foreign relations ${ }^{28}$ ". The United States had established consular offices in Dublin, Cork, and Belfast, two of them since the 1790s, and on 27 July 1927 the career diplomat Frederick A. Sterling opened the US Legation. This was an elaborate ceremony in Dublin, as Sterling was met in Dún Laoghaire by President Cosgrave and taken in a cavalcade with military escort to present his credentials to the Governor-General, all of which was fully covered by the newspapers and the motion picture newsreels ${ }^{29}$.

Ireland had consulates and trade missions in Boston, New York, and San Francisco in the US and several European cities - legacies from the Dáil efforts to secure recognition during the Anglo-Irish War. In 1929 Count Gerald O'Kelly de Gallagh was appointed Minister to France, Charles A. Binchy Minister to Germany, and Charles Bewley Minister to the Vatican, and Legations were

27. For Canadian negotiations to establish diplomatic relations with the United States see, H. Gordon Skilling, Canadian Representation Abroad: From Agency to Embassy (Toronto, Ryerson Press, 1945), p. 200-16; C.P. Stacey, Canada and the Age of Conflict: The Mackenzie King Era, 1921-1948 (Toronto, University of Toronto Press, 1981) vol. II, p. 89-97; and John Hilliker, Canada's Department of External Affairs: The Early Years, 1909-1946 (Montreal and Kingston: McGill-Queen's University Press, 1990), vol. I, p. 81 and 111-13.

28. Joseph P. Walshe to the Private Secretary of the Minister of Justice, 21 October 1924, Documents on Irish Foreign Policy, Volume II, 1923-1924 (Dublin, Irish Royal Academy, 2000), p. 360.

29. Bernadette Whelan, United States Foreign Policy and Ireland: From Empire to Independence, 1913-29 (Dublin, Four Courts Press, 2006), p. 346-526; and Troy D. Davis, "Diplomacy as Propaganda: The Appointment of T.A. Smiddy as Irish Free State Minister to the United States”, Eire-Ireland, vol. 31, n ${ }^{\text {os }} 3 \& 4$ (Winter, 1996), 117-29. The Secretary of the Department of External Affaires, Joseph P. Walshe, wrote to the Minister of Justice shortly after Smiddy had presented his credentials in Washington, pointing out that this appointment was "the main accomplishment in our external relations"... He further noted that "America is the only country with which our relations are entirely free and independent from any outside control", and that these direct bi-lateral took foreign affairs out of the hands of the Foreign Office in London. Joseph P. Walshe to the Private Secretary to the Minister of Justice, 22 October 1924, Documents on Irish Foreign Policy, Volume II, 1923-1926, p. 360. 
opened in the next decade in Belgium, Spain, Italy, Canada, Switzerland, and Portugal. The promotion of trade and tourism was a significant part of the duties of these diplomats, but even more important was the task of sending a message to the international community, as well as to the Irish communities at home and abroad, that Ireland had taken her place among the nations of the earth. Diplomatic relations were seen as the hallmark of sovereignty. As Desmond Fitzgerald, the Minister of External Affairs asserted on the eve of recognition by the United States, recognition "means we, as a sovereign State, speak directly to other sovereign States through our own fully-accredited Plenipotentiary 30 ". To drive home this message, Cosgrave undertook a very public visit to the United States and Canada in January 1928, in which he visited and spoke to Irish groups in Chicago, Philadelphia, New York, and Ottawa. The highlight of his trip was a luncheon with President Calvin Coolidge in Washington and ceremonies in both the Senate and the House of Representatives. Here was the head of an Irish government meeting with the President of the United States in the White House and with political leaders in Congress, all of which was reported in newspapers and motion picture newsreels in Ireland and abroad. Partially as a result of this visit, Cosgrave also went to Paris to sign the Kellogg-Briand Peace Pact on 27 August 1928, and he accompanied Secretary of State Frank B. Kellogg back to Dublin for a highly publicized official visit, the first visit to Ireland by a senior American statesman ${ }^{31}$. This was an extraordinary compliment to Ireland because Kellogg was only the third Secretary of State to visit Europe while in office.

The Irish Free State made tremendous strides in establishing itself as independent at the League of Nations, through the several Commonwealth meetings, and through international diplomacy. Even de Valera was obliged to acknowledge privately that: "They [the Cosgrave government] had done a magnificent job ${ }^{32}$." When Eamon de Valera came into office in 1932 he took the External Affairs portfolio himself. He also retained Joseph P. Walshe as Secretary of External Affairs, thus maintaining continuity in shaping a professional foreign service, but Irish foreign affairs were given a new focus. Commonwealth participation, in which Ireland had been very active, was de-emphasized and overseas relations, such as with the United States, became less central. De Valera had more ambitious plans for changing Ireland's bi-lateral relations with Britain, which became a central theme of de Valera's foreign and domestic policies and which he could

30. Dermot Keogh, Ireland and Europe, op. cit., p. 23-33; and Dáil Éireann deb., vol. 8, col. 803; 9 July 1924.

31. Bernadette, Whelan, United States Foreign Policy and Ireland, op. cit., p. 556-60; Francis M. Carroll, "The Irish Free State and Public Diplomacy: The First Official Visit of William T. Cosgrave to the United States", New Hibernia Review, vol. 16, n 2 (Summer, 2012), p. 77-97; and Francis M. Carroll, "Protocol and International Politics, 1928: The Secretary of State Goes to Ireland”, Eire-Ireland, vol. 26, n 4 (Winter, 1991), 45-57.

32. From an interview with Vivion de Valera by Tim Pat Coogan, in Tim Pat Coogan, De Valera: Long fellow, Long Shadow, op. cit., p. 426. 
do legally on the strength of the Balfour Declaration and the Statute of Westminster ${ }^{33}$. Relations with Britain were initially strained by de Valera's decision to retain the land annuities payments - effectively the repayment of the earlier loans to enable Irish farmers to purchase land from landlords. In retaliation the British government placed import duties on Irish cattle and dairy products, leading to a six-year trade dispute. Paralleling these matters, de Valera began work revising the constitution of the Irish Free State, abolishing the Oath of Allegiance to the King, diminishing the role of the Governor-General, and later dissolving the Senate. The abdication of King Edward VIII in December of 1936 also provided the opportunity to remove reference to the King and the Governor-General in the existing constitution. The king retained a role in the appointment of Irish diplomats and Ireland remained a member of the Commonwealth. Following talks between de Valera and Malcolm MacDonald, the Dominion Secretary, in London on 14 January 1937, the door was opened for a settlement of the land annuities and other issues. By spring of 1937 de Valera had put together a new constitution that, among other things, confirmed the changed relationship with Britain, provided for an elected President, and created a new Seanad. Ireland was effectively independent from Great Britain and with a tenuous connection to the Empire and the Commonwealth. De Valera's statement in the Dáil in April of 1935 was becoming a fact: "Though we are in the British Commonwealth to-day we are not of it $^{34}$." Ireland was an independent republic in all but name, as many have said, albeit without the six counties of Northern Ireland.

Although the British Prime Minister Neville Chamberlain's reputation is forever colored by his unsuccessful dealings with Adolph Hitler and his failure to get Britain in a state of readiness to meet the war crisis in the late 1930s, it must be said that his policy of "appeasement" toward the Irish was a success. In February 1938 agreement was reached resolving the annuities question through a single payment to Britain of $£ 10,000,000$ and the extension to Ireland of preferential trade access to British markets and the restoration of the bases at Cobh, Lough Swilly, and Berehaven, held by the Royal Navy under the Anglo-Irish Treaty. The settlement of these issues was a major accomplishment in terms of both normalizing Ireland's bi-lateral relations with Britain and enhancing Ireland's independence on the eve of the $\operatorname{war}^{35}$. The return of the naval bases particularly

33. Fanning says that de Valera wanted to "bend the machinery of government to his own purpose, not dismantle it". However, the combination of international events and de Valera's own objectives led to profound changes in Irish foreign policy. Ronan Fanning, Independent Ireland, op. cit., p. 109. Also see, Aengus Nolan, Joseph Walshe, op. cit., p. 58-59.

34. Dáil Éireann deb., vol. 55, col. 2276; 10 April 1935; and Alan J. Ward, The Irish Constitutional Tradition: Responsible Government and Modern Ireland, 1782-1992 (Washington, D.C., Catholic University of America Press, 1994), p. 212-95.

35. The first steps in easing the land annuities-trade dispute came in the 1934 coal-cattle agreements. See Paul 
had two important consequences for Ireland. First, it allowed Ireland to be neutral and to stay out of the war in a way that would have been quite impossible if Royal Navy ships had been sailing from several ports in Éire. Second, it ensured a degree of domestic tranquility during the war by removing a series of targets that would have been irresistible to the IRA.

As the 1930s unfolded, the international situation darkened. The ominous shadow of war spread across Asia, Africa, and Europe, and international relations took on a more life-and-death urgency. Moreover, as the League of Nations declined, de Valera had to deal with more dangerous international problems ${ }^{36}$. Neutrality, one area of foreign policy that has been closely examined by historians, became the deliberate choice by the de Valera government and appears to have been widely supported throughout the country. "Neutrality has given the people more faith in what the Government has achieved for the independence of this country than any other act of theirs", Joseph P. Walshe, Secretary of the Department of External Affairs ${ }^{37}$ wrote. Indeed, it has been argued that joining the Allies would have divided the country, revived the IRA, and brought civil war back to Ireland. Although de Valera seems to have had no misgivings about his decision to keep Ireland out of the war, he came under intense pressure to join the Allies from the two foreign powers that were most important to Ireland - Britain and the United States ${ }^{38}$. British Prime Minister Winston Churchill's veiled assurance that if Ireland entered the war the partition would be ended was turned down by de Valera, and strong urgings by American Minister David Gray and other officials were also rebuffed. Indeed, the mission of Frank Aiken, Minister of Defence, to the United States in April of 1941 to appeal directly to President Roosevelt for military aid met with a very frosty reception. When Aiken indicated that Ireland needed weapons to defend against an invasion by the British, Roosevelt said: "Nonsense... England is not going to invade you. It's a preposterous sugges-

Canning, British Policy Towards Ireland, 1921-1941 (Oxford, Clarendon Press, 1985), p. 121-220; and McMahon, Republicans and Imperialists, p. 157-62 and p. 222-26. For a glimpse of these events from the perspective of de Valera's role, see Longford and O’Neill, Eamon de Valera: A Biography, p. 273-326; T. Ryle Dwyer, De Valera's Finest Hour, 1932-1959 (Cork, Mercier Press, 1982), p. 51-114; and Coogan, De Valera, p. 430-60.

36. Michael Kennedy, Ireland and the League of Nations, p. 189-257. De Valera strongly supported Chamberlain in the Munich crisis.

37. Memorandum from Joseph P. Walshe to Eamon de Valera, 1 July 1940, Documents on Irish Foreign Policy, Volume VI, 1939-1941 (Dublin, Royal Irish Academy, 2008), p. 271-72. Just a week and a half earlier Walshe had assured de Valera that "Britain's defeat has been placed beyond all doubt". Memorandum from Joseph P. Walshe, 21 June 1940, Ibid., p. 249-50. Also see Trevor C. Salmon, Unneutral Ireland: An Ambivalent and Unique Security Policy (Oxford, Clarendon Press, 1989), p. 82-119.

38. T. Ryle Dwyer, Irish Neutrality and the USA 1939-47 (Dublin, Gill and Macmillan, 1977), p. 1-23 and 179200; T. Ryle Dwyer, Guests of the Nation: The Story of Allied and Axis Servicemen Interned in Ireland During World War II (Dingle, Brandon Books, 1994), passim; Ian S. Wood, Britain, Ireland and the Second World War (Edinburgh, Edinburgh University Press, 2010), 1-19; and John A. Murphy, "Irish Neutrality in Historical Perspective", in Brian Girvin and Geoffrey Roberts, Ireland and the Second World War, op. cit., p. 7-23. 
tion ${ }^{39}$." Bi-lateral relations between Ireland and the United States reached an alltime low in 1944 with Gray's strongly worded note that the German and Japanese missions be closed ${ }^{40}$. In terms of practical politics, however, Ireland's neutrality was practiced in ways that were highly beneficial to the Allies - more "non-belligerency" than impartial neutrality. Atlantic weather reports and the movement of ships in coastal waters were broadcast in English, anti-submarine flights were given permission to over-fly Irish territory, Allied prisoners were well treated and allowed to "escape" across the border, and thousands of Irish were free to join the British forces or work in British war industries ${ }^{41}$. More confidentially, Irish police and military intelligence and the Irish Ministry for External Affairs worked closely with British intelligence and the Dominions Office to insure that no clandestine German activity could take place and that no security breaches jeopardized Allied operations, such as the Normandy invasion. Early in the crisis extended plans were developed with the British about what joint operations could be mounted if the Germans did invade ${ }^{42}$. That said, de Valera maintained highly public rela-

39. Letter from Robert Brennan to Joseph P. Walshe 10 April 1941, Documents on Irish Foreign Policy, Volume VII, 1941-1945 (Dublin, Royal Irish Academy, 2010), p. 44-46; T. Ryle Dwyer, Strained Relations: Ireland at Peace and the USA at War, 1941-45 (Dublin, Gill \& Macmillan, 1988), p. 118-54; Paul Bew (ed.), A Yankee in de Valera's Ireland: The Memoir of David Gray (Dublin, Royal Irish Academy, 2012), passim. Also see Joseph Rosenberg, "The 1941 Mission of Frank Aiken to the United States: An American Perspective", Irish Historical Studies, vol. 22, nº 86 (September, 1980), p. 162-77; Raymond James Raymond, "David Gray, the Aiken Mission, and Irish Neutrality, 1940-41, Diplomatic History, vol. 9, n ${ }^{\circ} 1$ (Winter, 1985), p. 55-71; and Dwyer, Irish Neutrality, p. 107-21. Aiken was understood to have said in Portugal on his way to the United States that Ireland would have no objection to a German victory in the war, and his subsequent courting of Irish-American groups hostile to the Roosevelt administration did not help his mission either.

40. For the provocative request, see Letter from David Gray to Eamon de Valera, "The American Note", 21 February 1944, Documents on Irish Foreign Policy, Volume VII, 1941-1945, p. 379-80. Also see Troy D. Davis, Dublin's American Policy: Irish-American Diplomatic Relations, 1945-1952 (Washington, D.C., Catholic University of America Press, 1998), p. 1-28.

41. Thomas E. Hachey, The Rhetoric and Reality of Irish Neutrality", New Hibernia Review, vol. 6, n ${ }^{\circ} 4$ (Winter, 2002), p. 26-43; Trevor C. Salmon, Unneutral Ireland, op. cit., p. 120-54; and Patrick Keatinge, A Singular Stance: Irish Neutrality in the 1980s (Dublin, Institute of Public Administration, 1984), p. 17-24. The exact figures of Irish citizens serving in the British forces seems impossible to determine, but at least 42,665 were identified by the British government, while 165,000 listed Irish addresses for next of kin. The number of Irish citizens who worked in British industries during the war is also difficult to calculate, but the figure may be something between 172,574 and 189,942. See Richard Doherty, "Irish Heroes of the Second World War", and Tracey Connolly, "Irish Workers in Britain During World War Two", in Brian Girvin and Geoffrey Roberts (eds.), Ireland and the Second World War (Dublin Four Courts Press, 2000), p. 91-95 and 121-32; and Eunan O'Halpin, Spying on Ireland: British Intelligence and Irish Neutrality During the Second World War (Oxford, Oxford University Press, 2008).

42. Eunan O’Halpin, ibid.; and Carolle Carter, "Ireland: America’s Neutral Ally, 1939-1941”, Eire-Ireland, vol. 12, $\mathrm{n}^{\circ} 1$ (Spring, 1977), p. 5-13. For Irish relations with Germany, see, Niall Keogh, Con Cremin: Ireland's Wartime Diplomat (Cork, Mercier Press, 2008), p. 18-93. For Irish relations with Germany see Michael Kennedy, "Our Men in Berlin: Some Thoughts on Irish Diplomats in Germany, 1929-39”, Irish Studies in International Affairs, vol. 10 (1999), p. 53-70; Mervyn O'Driscoll, Ireland, Germany and the Nazis: Politics and Diplomacy, 19191939 (Dublin, Four Courts Press, 2004); and John P. Duggan, Neutral Ireland and the Third Reich (Dublin, Gill \& Macmillan, 1989). 
tions with the German Legation, to the extent of paying his condolences on 2 May 1945 on the death of Adolph Hitler - what Dermot Keogh considers to have been "the worst decision of his sixteen-year term as Minister of External Affairs ${ }^{43}$ ". This infuriated the Allies, led to Churchill's public criticism of Ireland in the course of his victory speech, and served to isolate Ireland in the post-war era. It should be said that de Valera's measured reply to Churchill in a radio speech won him great praise in Ireland, but probably less so in Britain and the United States. However, this gesture did highlight the degree to which Ireland had pursued a foreign policy distinctly independent from that of Great Britain and the United States. "Neutrality", Patrick Keatinge concluded, was "the ultimate proof of sovereignty ${ }^{44} . .$. " No one could doubt Ireland's sovereignty or independence.

The Second World War ended with Ireland's independence well demonstrated, but with the avenues of its early foreign policy in disarray and destined to get worse. The League of Nations had been overtaken by the events of the war and rendered irrelevant. The closing meeting of the Assembly was held in April of 1946. In the meantime the United Nations had held its organizational meeting in San Francisco in May of 1945 and its first meeting of the General Assembly in November. The United Nations had looked like a victors' club to many in the Irish Ministry of External Affairs and no effort had been made to be included in the early organization of the association ${ }^{45}$. When Ireland did apply for membership in the summer of 1946 ("without enthusiasm", in the words of Conor Cruise O’Brien) the application was vetoed by the Soviets ${ }^{46}$.

Commonwealth relations might have offered a means of maintaining workable links with similar countries, but Ireland had distanced itself from the Commonwealth both before and during the $\operatorname{war}^{47}$. In the February 1948 general

43. The visit was "was an egregious error in judgment", Keogh concludes. Keogh, Ireland and Europe, p. 191; Clair Wills, That Neutral Ireland: A Cultural History of Ireland During the Second World War (London, Faber and Faber, 2007), p. 383-422; and Joseph T. Carroll, Ireland in the War Years, 1939-1945 (Newton Abbot, David \& Charles, 1975), p. 160-79.

44. Patrick Keatinge, "Unequal Sovereigns: The Diplomatic Dimension of Anglo-Irish Relations”, in P.J. Drudy (ed.), Ireland and Britain Since 1922 (Cambridge, Cambridge University Press, 1986), p. 142. In his radio broadcast to the Irish nation on 16 May 1945 de Valera asked why, in a war ostensibly fought to resist aggression and the violation of international law, Churchill, in the moment of victory, would raise the issue of the possible invasion of Éire on the basis of Britain's national self interest. See "National Thanksgiving", in Moynihan (ed.), Speeches and Statements of Eamon De Valera, p. 47-77. Although F.S.L. Lyon's analogy of the watchers in Plato's cave, observing the shadows of others on the wall, has been strongly criticized, Ireland's successful neutrality did tend to leave the country outside the most cataclysmic and transformational events of the century. F.S.L. Lyons, Ireland Since the Famine, op. cit., p. 551.

45. Michael Kennedy, Ireland and the League of Nations, p. 247-50; and Troy D. Davis, Dublin's American Policy, op. cit., p. 29-57.

46. Gerard O’Brien, "Ireland in International Affairs", op. cit., p. 127.

47. Dermot Keogh shows that the Soviet attitude towards Irish membership in the United Nations was at least partially influenced by Ireland's neutrality during the war, by the country's alleged sympathy for the Axis Powers, and by the supposedly "fascist" nature of de Valera's government. Dermot Keogh, Ireland and Europe, op. cit., p. 202-205. 
elections a coalition government headed by John A. Costello of the Fine Gael replaced that of Eamon de Valera after sixteen years. Sean MacBride, who had been IRA Chief of Staff in 1936, but who had formed his own constitutional party called Clann na Poblachta, was made Minister for External Affairs. In the following July both MacBride and Costello made public statements that Éire was not a member of the Commonwealth, McBride repeating three times in the Dáil that, "We are clearly not part of the British Commonwealth. We are clearly a sovereign and independent state ${ }^{48}$ ". Nevertheless, Costello went off to a meeting of Commonwealth Prime Ministers in Ottawa in September 1948. Historians are still probing the subsequent sequence of events and the matters of cause and effect $^{49}$. On 5 September the Dublin Sunday Independent reported that the External Relations Act - the link with the Crown - would be repealed. Two days later, on 7 September, while in Ottawa, Costello confirmed that the legislation would be "ditched", and back in Dublin MacBride and colleagues began drafting legislation to repeal the External Relations Act. This became the Republic of Ireland Bill 1948 which broke the Commonwealth connection and changed the name of the country from Éire to the Republic of Ireland. MacBride and others had made no secret of their sentiments about a republic and about the Commonwealth, but had the Cabinet worked out a plan earlier in the summer? Or had Costello been so angered by the imperious manner of Lord Alexander of Tunis, the GovernorGeneral of Canada and the host at the Ottawa meetings, that he impetuously went ahead and set in motion the termination of the Commonwealth link and finalized the republican status of Ireland? The British response to these announcements was to withdraw the invitation to Costello to participate in the next Commonwealth Prime Ministers conference and to pass the Northern Ireland Bill 1949, in which Parliament assured Northern Ireland that there would be no change in the status of the province without the consent of the Stormont legislature. This seemed a major blow to the aspirations of both Fianna Fáil and Fine Gael to bring the six counties back into the country ${ }^{50}$.

Bi-lateral relations with the United States, Britain, and even France were at a low point largely because of Ireland's neutrality policy during the war. Close relations between the Irish legation and the Vichy government during the war

48. Dáil Éireann deb., vol. 112, cols. 988, 1019, and 1020; 21 July 1948.

49. Ronan Fanning, Independent Ireland, op. cit., p. 177-80; and J.J. Lee, Ireland, 1910-1985, p. 300-402.

50. Ian McCabe, A Diplomatic History of Ireland, 1948-49: The Republic, the Commonwealth and NATO (Dublin, Irish Academic Press, 1991), p. 20-96; Ronan Fanning, "The Response of the London and Belfast Governments to the Declaration of the Republic of Ireland, 1948-49", International Affairs, vol. 58, n 1 (Winter, 1981-82), p. 95-114; and D.W. Dean, "Final Exit? Britain, Eire, the Commonwealth and the Repeal of the External Relations Act, 1945-1949”, Journal of Imperial and Commonwealth History, vol. 20, n 3 (1992), p. 391-418. Lowry shows that de Valera would have kept Ireland in the Commonwealth and in fact consulted with India about membership in the Commonwealth as a republic. Lowry, "The Captive Dominion: Imperial Realities Behind Irish Diplomacy”, p. 223-28. 
proved to be a problem by 1944 and 1945 , following the liberation of France ${ }^{51}$. The opportunity to rebuild ties to the United States was lost in February of 1949 when Ireland was invited to join the North Atlantic Treaty Organization as it was being formed. MacBride insisted that Ireland could join an alliance with Britain only on the condition that the six counties of Northern Ireland were united with the Republic, although by this time the idea of non-alignment, not to mention neutrality, was also a factor ${ }^{52}$.

Looking at the history of the first twenty-five years of independence, it is important to keep in mind that Ireland persistently pursued its own interests through a multi-dimensional foreign policy and met both with brilliant success and discouraging setbacks. From 1923 on Irish governments and their diplomatic service had invested great amounts of time and energy to making a success of international relations.

One may or may not agree with Conor Cruise O'Brien's observation that in its first twenty-five years, "the Irish State played a more momentous and influential part in international affairs than it was ever to play again ${ }^{53}$ ". Ireland had pursued an assertive foreign policy distinct from, if not actually in defiance of, the great powers. Ireland achieved and maintained its independence, but at a cost. Michael Kennedy has claimed that it would take Ireland over a decade "to recover the position she had lost during the war", although of course eventually she $\operatorname{did}^{54}$. The country had an international presence and diplomatic relations with a number of countries, although relations were quite strained with the most important ones the United States, Britain, and France. What must be kept in mind is that these international matters were an integral part of Ireland's emergence as a nation

51. Dermot Keogh notes that by 1945 relations with both France and the United States were strained. However, he concludes that the public exchange between Churchill and de Valera when the war ended did not have any lasting consequences, in part because of a change of government in Britain in July. Keogh, Ireland and Europe, op. cit., p. 182-90 and 190-200; and Dermot Keogh, "Ireland, de Gaulle and World War II", in Pierre Joannon (ed.), De Gaulle and Ireland (Dublin, Institute of Public Administration, 1991), p. 23-52; and Robert Patterson, "Ireland, Vichy and Post-Liberation France, 1938-50", in Michael Kennedy and Joseph Morrison Skelly, Irish Foreign Policy, op. cit., p. 96-115.

52. James I. McCabe, A Diplomatic History of Ireland, op. cit., p. 97-148; Paula L. Wylie, Ireland and the cold War: Diplomacy and Recognition, 1949-63, Dublin, Irish Academic Press, 2006; and Davis, Dublin's American Policy, p. 95-173; and Bernadette Whelan, Ireland and the Marshall Plan, 1947-1957 (Dublin, Four Courts Press, 2000).

53. Gerard O’Brien, "Ireland in International Affairs", op. cit., p. 108-09. Perhaps a more generous explanation might be found in Lyon's conclusion, "At the very moment when she [Ireland] had achieved stability and full independence, and was ready to take her place in the society of nations, that society dissolved and she was thrown back upon her own meagre resources". F.S.L. Lyons, Ireland Since the Famine, op. cit., p. 551.

54. Michael Kennedy, Ireland and the League of Nations, op. cit., p. 250. Keogh argues that the view that Ireland was isolated by 1945 is "quite mistaken", although he is quite critical of the "inexperience and impetuosity" of de Valera’s successors in 1948 and 1949. Dermot Keogh, Ireland and Europe, op. cit., p. 208 and 211-12. Also see, Thomas E. Hachey, "Nuanced Neutrality and Irish Identity: An Idiosyncratic Legacy", in Thomas E. Hachey (ed.), Turning Points in Twentieth-Century Irish History (Dublin, Irish Academic Press, 2011), p. 77-102. 
state and not just a series of interesting anecdotes. The international history must become part of the national narrative. It has been the process through which Ireland has fulfilled the charge embodied in Robert Emmet's speech from the dock for Ireland to take her place "among the nations of the earth". Certainly with the current availability of both manuscript and published documents and a growing body of monographs and special studies, Ireland's international history will become a central part of an understanding of the emergence of the modern Irish state. 